УДК 37.091.279.7:004

Макаренко Олена Леонідівна

аспірант, викладач кафедри комп’ютерної інженерії та освітніх вимірювань

Національний педагогічний університет імені М. П. Драгоманова, м. Київ, Україна

olmakarenko0307@gmail.com

\title{
ВИКЛАДАННЯ ДИСЦИПЛІНИ «ОСНОВИ ОСВІТНІХ ВИМІРЮВАНЬ» З ВИКОРИСТАННЯМ ЗАСОБІВ СИСТЕМИ МООDLЕ
}

\begin{abstract}
Анотація. Засоби дистанційного навчання все частіше використовуються в університетах під час аудиторної навчальної діяльності. Така практика має місце й у Національному педагогічному університеті імені М. П. Драгоманова в процесі підготовки магістрів 3 освітніх вимірювань. Стаття присвячена висвітленню питання використання засобів системи Moodle у процесі викладання пропедевтичного курсу «Основи освітніх вимірювань» для студентів магістратури денної заочної форм навчання. Описано структурні елементи дисципліни i їх зміст. Представлено досвід наповнення дистанційного курсу дисципліни 3 використанням функціоналу системи Moodle для проведення лекційних $\mathrm{i}$ семінарських занять, контролю виконання студентами вимог програми й оцінювання рівня засвоєння ними навчального матеріалу.
\end{abstract}

Ключові слова: магістри $з$ освітніх вимірювань; підготовка; магістратура; дистанційний курс; викладання дисципліни; Moodle.

\section{1. ВСТУП}

Постановка проблеми. Система Moodle, яка від самого початку розроблялася як середовище для організації дистанційної форми навчання, набула величезної популярності завдяки своїй багатофункціональності й можливості використання для організації всіх інших форм навчання. Частково це пов'язано з тим, що ми навчаємо покоління Z, яке використовує інформаційні технології в процесі майже будь-якої діяльності, у тому числі й навчальної. Представники цього покоління навчаються постійно. Якщо викладач буде правильно використовувати засоби IКТ, то ефективність навчання буде підвищуватися як у контексті підготовки студентів дистанційної й заочної форм, так і студентів стаціонарної форми. Це твердження є одним із тих, на яких базується організація освітнього процесу професійної підготовки магістрів 3 освітніх вимірювань (ОВ) у Національному педагогічному університеті імені М. П. Драгоманова. Специфіка цієї спеціальності викликана такими основними причинами: 1) різносторонність напрямів базової вищої освіти вступників; 2) широкий віковий діапазон студентів; 3) різний рівень ознайомлення студентів із вимірюваннями в освіті, їхніми основними компонентами і напрямами застосування. Тож, у результаті оновлення навчального плану підготовки магістрів 3 освітніх вимірювань у НПУ імені М. П. Драгоманова було введено пропедевтичний курс «Основи освітніх вимірювань», який у експериментальному порядку реалізовувався 3 активним застосуванням засобів системи Moodle.

Аналіз останніх досліджень і публікацій. Проблемам i можливостям використання системи Moodle в навчальному процесі присвячено розвідки багатьох педагогів: В. П. Бригінця, В. В. Гавриленка, О. В. Матвійчука, С. О. Подласова, В. Д. Попенка, О. С. Сокульського, Ю. В. Триуса,В. М. Франчука, О. А. Шумейка. Питання застосування Moodle під час викладання тих чи інших навчальних дисциплін розглядали Н. В. Гатальська, В. М. Кухаренко, I. В. Тищенко, М. А. Умрик, Г. А. Чередніченко, Л. Ю. Шапран, Ю. О. Швець та ін. Щодо підготовки магістрів 3 
освітніх вимірювань, то різні эї аспекти досліджували О. В. Авраменко, Т. В. Бодненко, Ю. О. Ковальчук, Л. О. Кухар,Т. В. Лісова, С. А. Раков, В. П. Сергієнко та інші. Проте в результаті здійсненого аналізу наукових джерел виявлено, що питання використання засобів системи Moodle під час викладання дисципліни «Основи освітніх вимірювань» не висвітлювалося в науковій літературі.

Тому метою статті $є$ висвітлення питання викладання пропедевтичного курсу «Основи освітніх вимірювань» 3 допомогою використання засобів системи Moodle для магістрантів з освітніх вимірювань денної і заочної форм навчання.

\section{2. МЕТОДИКА ДОСЛІДЖЕННЯ}

Описуване в статті дослідження проводилося в рамках виконання дисертаційного роботи «Підготовка магістрів з освітніх вимірювань у педагогічному університеті», де впровадження пропедевтичного курсу «Основи освітніх вимірювань» розглядається як одна з умов підвищення ефективності процесу професійної підготовки.

На підготовчому етапі дослідження нами розроблено дистанційний курс на основі навчальної і робочої програм дисципліни «Основи освітніх вимірювань» і апробовано його на основному етапі дослідження в навчальному процесі професійної підготовки магістрів 3 освітніх вимірювань у НПУ імені М. П. Драгоманова (30 студентів: 18 денної форми і 12 - заочної). У рамках дослідження було використано такі методи: спостереження, тестування, анкетування, узагальнення, аналіз, синтез.

Зокрема, спостереження було цінне тим, що дозволило слідкувати за перебігом навчального процесу в природних умовах. Водночас, цей метод забезпечив організоване і цілеспрямоване дослідження реакції студентів на зміст навчального матеріалу, на форми, методи та засоби викладання, а саме поєднання традиційних засобів і засобів системи Moodle. Також зазначений метод допоміг виявити переваги, складнощі та недоліки в роботі 3 дистанційним курсом; сформувати певні судження про загальну зацікавленість магістрантів і рівень їхньої мотивації до навчання в такому форматі. У процесі спостереження викладач фіксував усе, що відбувалося під час вивчення дисципліни як під час аудиторної, так і позааудиторної навчальної діяльності. Метод тестування використовувався, щоби виміряти рівень отриманих студентами знань, набутих умінь і сформованих компетентностей. Метод анкетування - для вимірювання ефективності викладання описуваного пропедевтичного курсу і збирання відомостей щодо подальших перспектив його удосконалення. Узагальнення, аналіз та синтез використовувалися на останньому етапі дослідження для підведення підсумків і прийняття відповідних рішень.

\section{3. РЕЗУЛЬТАТИ ДОСЛІДЖЕННЯ}

\section{1. Зміст матеріалу пропедевтичного курсу}

«Основи освітніх вимірювань» - це пропедевтичний курс, який передбачає скорочений виклад основних понять, положень та аспектів галузі освітніх вимірювань. У зв'язку зі своєю специфікою дисципліна має міждисциплінарні зв'язки з більшістю дисциплін навчального плану, серед яких «Наукові основи конструювання тестів», «Математико-статистичні методи в освітніх вимірюваннях», «Рейтингове оцінювання в системі освіти i науки», «Експертне оцінювання в освітніх вимірюваннях», «Моніторинг якості освіти», «Зовнішне незалежне оцінювання», «Методологія та методи наукових досліджень у освітніх вимірюваннях», «Освітня політика», «Когнітивна психологія та психометрія» тощо. 
Метою викладання навчальної дисципліни $€$ ознайомлення магістрантів 3 основними поняттями, положеннями, напрямами використання i завданнями вимірювань в освіті; створення умов для успішного й поглибленого подальшого опанування дисциплін навчального плану; підвищенні зацікавленості в новій спеціальності та мотивації до їі засвоєння. Відповідно, основними завданнями вивчення дисципліни «Основи освітніх вимірювань» $є$ :

- формування знань про освітні вимірювання як про систему знань, наукову галузь і процес присвоєння числових значень латентним характеристикам особистості;

- ознайомлення студентів 3 основними компонентами, напрямами та завданнями освітніх вимірювань;

- ознайомлення 3 вітчизняним i зарубіжним досвідом у галузі освітніх вимірювань;

- викладення сутності процесів тестування, оцінювання, контролю, діагностики, моніторингу, рейтингування в освіті.

Після завершення зазначеного курсу магістранти мають досягти запланованих результатів навчання в контексті відповідних компетентностей (табл. 1).

Таблиия 1

Результати навчання і компетентності, заплановані у рамках вивчення дисципліни «Основи освітніх вимірювань»

\begin{tabular}{|c|c|c|}
\hline $\begin{array}{l}\text { № } \\
\text { 3/ח }\end{array}$ & Результати навчання & Компетентності \\
\hline 1. & $\begin{array}{l}\text { 3нати: } \\
\text { - науково-понятійний апарат освітніх вимірювань; } \\
\text { - історію, сучасний стан і тенденції розвитку процесів } \\
\text { оцінювання, тестування, моніторингу, рейтингування в } \\
\text { освіті; } \\
\text { - принципи, цілі, завдання, критерії, види та методи } \\
\text { оцінювання в освіті; } \\
\text { - класифікацію, шляхи використання, вимоги до } \\
\text { тестових завдань і тестів; } \\
\text { - концептуальні засади моніторингових досліджень; } \\
\text { - види, методи формування, напрями застосування } \\
\text { рейтингів в освіті. } \\
\text { Уміти: } \\
\text { - розробляти критерії оцінювання; } \\
\text { - конструювати й аналізувати тестові завдання; } \\
\text { - компонувати банк тестових завдань відповідно до } \\
\text { когнітивних рівнів; } \\
\text { - розробляти матрицю тесту; } \\
\text { - створювати тест } 3 \text { урахуванням мети й очікуваних } \\
\text { результатів; } \\
\text { - здійснювати базовий математико-статистичний аналіз } \\
\text { тестових завдань і тестів; } \\
\text { - планувати моніторингове дослідження; } \\
\text { - інтерпретувати результати тестування, моніторингу. }\end{array}$ & $\begin{array}{l}\text { Загально- } \\
\text { професійні і } \\
\text { спеціально- } \\
\text { професійні }\end{array}$ \\
\hline
\end{tabular}




\begin{tabular}{|c|c|c|}
\hline 2. & $\begin{array}{l}\text { Знати: } \\
\text { - світові і вітчизняні наукові досягнення галузі; } \\
\text { - сутність освіти як результату і як процесу; } \\
\text { - особливості освітніх вимірювань як науки. } \\
\text { Уміти: } \\
\text { - засвоювати і реалізовувати в професійній діяльності } \\
\text { сучасні наукові дослідження в галузі освіти й освітніх } \\
\text { вимірювань; } \\
\text { - використовувати окремі загальнонаукові і специфічні } \\
\quad \text { методи наукових досліджень. }\end{array}$ & Загальнонаукові \\
\hline 3. & $\begin{array}{l}\text { 3нати: } \\
\text { - українську мову на високому рівні; } \\
\text { - іноземну мову на достатньому рівні; } \\
\text { - базові основи комп'ютерних технологій. } \\
\text { Уміти: } \\
\text { - здійснювати пошук відомостей із різних джерел, } \\
\text { логічно і системно їх опрацьовувати; } \\
\text { - використовувати ІКТ для розв'язання широкого кола } \\
\text { професійних і соціальних завдань; } \\
\text { - застосовувати лінгвістичні здібності в навчальній і } \\
\text { професійній діяльності. }\end{array}$ & Інструментальні \\
\hline 4. & $\begin{array}{l}\text { Знати: } \\
\text { - норми моральної й етичної поведінки; } \\
\text { - основи етики ділового спілкування; } \\
\text { - методи самоаналізу і саморозвитку. } \\
\text { Уміти: } \\
\text { - працювати в команді й індивідуально; } \\
\text { - творчо підходити до виконання поставлених завдань і } \\
\text { розв'язання проблемних ситуацій; } \\
\text { - висловлювати свої міркування і демонструвати свої } \\
\text { напрацювання за результатами самостійної роботи. }\end{array}$ & $\begin{array}{l}\text { Соціально- } \\
\text { особистісні }\end{array}$ \\
\hline
\end{tabular}

Дисципліна «Основи освітніх вимірювань» за навчальним планом підготовки магістрів належить до нормативної частини циклу професійної і практичної підготовки, що вивчається в I семестрі. На вивчення курсу відводиться 3 кредити або 90 навчальних годин, 3 яких 64 години відведені на самостійну навчально-пізнавальну роботу студентів, а 26 годин - на аудиторні заняття, які проводяться у формі лекційних занять (14 год.) і семінарських занять (12 год.).

Весь матеріал дисципліни розділено на два модулі: «Освітні вимірювання в інформаційному суспільстві» i «Роль освітніх вимірювань у забезпеченні якості освіти». Для глибшого розуміння змісту дисципліни вважаємо за доцільне детально висвітлити тематику занять.

Перша тема першого модуля: «Освітні вимірювання як наукова галузь, діяльність i процес» - передбачає розгляд питань, серед яких роль i значення освіти в постіндустріальному суспільстві; сутність якості освіти і сучасні вимоги до неї; місце контролю й оцінювання в освітньому процесі; історія виникнення якісних і кількісних оцінок навчальних досягнень; компоненти процесу розроблення стратегії оцінювання; взаємозв'язок між освітніми і педагогічними вимірюваннями; головні інструменти освітніх вимірювань. 
У рамках другої теми: «Вступ до текстології» - розглядаються історія застосування тестів у світовій і вітчизняній практиці; поняття про тести i їх класифікацію; відмінність педагогічних тестів від психологічних; поняття про критеріально-орієнтовані й нормативно-орієнтовані тести; основні вимоги до педагогічних тестів, поняття про тестові завдання і завдання в тестовій формі, їх класифікація; основи розроблення тестових завдань; конструювання тестів та методично-інструктивних матеріалів до них; розроблення технологічної матриці тесту.

Третя тема: «Робота $з$ тестовим матеріалом» - спрямована на надання відомостей про сутність експертної перевірки претестових завдань, методи В. Ангоффа, Д. Міллмана, Л. Недєльського, Д. Пофама; апробацію претестових завдань; показники якості тестових завдань; матрицю результатів тестування; формування банку тестових завдань; визначення показників складності й диференційної здатності, надійності, валідності тощо.

Остання тема модуля: «Спеціальне програмне забезпечення в галузі освітніх вимірювань» - передбачає розгляд комп'ютерних технологій у тестуванні; понять інформаційної безпеки процедур комп'ютерного тестування; програмних засобів для проведення тестування і для аналізу якості тестових завдань (MyTest, AditTestdesk, TSExam, Moodle).

Що стосується другого модуля, то він складається з трьох тем.

Завданням першої теми: «Моніторинг якості освіти»- $€$ висвітлення питань концептуальних засад моніторингу якості освіти; становлення і розвитку моніторингу якості освіти; об'єктів моніторингових досліджень в освіті; класифікації освітніх моніторингів; підходів до організації моніторингових досліджень.

Під час вивчення другої теми: «Рейтинги в освіті»- розглядається методологія побудови міжнародних, національних, локальних рейтингів на рівні вищої і загальної середньої освіти.

Остання тема модуля: «Наукові дослідження в галузі освітніх вимірювань» знайомить магістрантів із вітчизняними і міжнародними організаціями в галузі освітніх вимірювань, науковими форумами, конференціями, семінарами, де розглядаються нагальні питання галузі; науковими виданнями галузі освітніх вимірювань і дотичних галузей, а також із методологією проведення наукових досліджень у галузі ОВ.

Зазначені питання розглядаються студентами під час лекцій, засвоюються в процесі самостійної роботи й закріплюються на семінарських заняттях. Робота магістрантів із системою Moodle відбувається саме на останніх двох етапах.

Той факт, що кількість годин самостійної роботи студентів майже втричі перевищує кількість аудиторних годин є ще одним вагомим чинником поєднання традиційних засобів навчання із засобами системи Moodle. Самостійна робота полягає в опрацюванні додаткових джерел інформації і виділенні з усього масиву ключових і необхідних відомостей. Водночас, передбачено, що в позааудиторний час магістранти також вивчають матеріал лекцій, презентації до яких доступні в системі Moodle; готуються до семінарських занять по планах, які теж розміщені у відповідних секціях дистанційного курсу; виконують завдання, отримані на семінарських заняттях; готуються до модульних і підсумкового контролів, маючи наразі можливість консультуватися з викладачем у чаті курсу в зручний для обох час.

Одним із найголовніших елементів самостійної роботи курсує виконання студентами проектної роботи «Інтелект-карта». Технологія роботи над проектом полягає в тому, що кожна група, у складі 3-4 осіб, обирає одну з тем модулів і впродовж усього терміну вивчення дисципліни паралельно працює над створенням так званої карти знань і детального іiі опису у формі реферату. Електронні екземпляри карти знань i реферату студенти завантажують у середовище Moodle, a усно 
презентують результати своєї роботи на семінарському занятті, тема якого відповідає темі карти знань. Попри те, що проектна робота «Інтелект-карта» відіграє роль інструмента діагностики ефективності самостійної навчальної діяльності студентів, вона виконує низку додаткових функцій: формує в студентів уміння працювати в команді; шукати, опрацьовувати та аналізувати відомості з різних джерел; генерувати нові ідеї; розвиває креативність;розширює навички використання IКТ.

Отже, самостійна робота забезпечує студентоцентрованість під час викладання, де викладач виступає в ролі наставника, консультанта. Це надзвичайно актуально для організації навчального процесу для освітньо-кваліфікаційного рівня «магістр». Студенти на цьому рівні мають свідомо прагнути до самостійного навчання, а викладач зобов'язаний створити педагогічні умови для формування і розвитку в кожного студента бажання навчатися впродовж життя, бо тільки за цієї умови фахівець будьякого напряму стає успішним професіоналом, розвивається, удосконалює себе й оточуючий світ.

На перший погляд здавалося неістотним значення Moodle для організації i проведення лекційних занять. Однак це виявилося хибним міркуванням, оскільки презентації лекцій, які були розміщені в середовищі, використовувалися студентами не лише у підготовці до семінарів чи для розроблення проектної роботи, а часто проглядалися наперед. Завдяки цьому реалізовувалися елементи технології «перевернутого класу». На нашу думку, лекція не повинна мати форму монотонного викладу матеріалу. Сучасному поколінню це не цікаво, а, отже, непродуктивно. Лекція повинна проходити з елементами конструктивного діалогу. Тому, коли деякі студенти приходили на лекції, знаючи частину матеріалу, це позитивно впливало на хід навчального процесу.

Під час проведення семінарських занять система Moodle використовувалася для актуалізації опорних знань і перевірки засвоєння навчального матеріалу. Зокрема, на початку кожного семінарського заняття студенти проходили короткий тест на визначення рівня опорних знань, необхідних для ефективної роботи на семінарі. Після тесту відбувалося обговорення винесених на заняття питань, усні відповіді, доповнення до них, дискусії тощо. Наприкінці семінарського заняття для закріплення знань і поточної перевірки кожному магістранту пропонувалося одне запитання з теми, на яке він повинен був відповісти письмово й надіслати свою відповідь викладачу 3 допомогою засобів системи Moodle.

Отже, для діагностики навчальних досягнень використовували такі форми поточного контролю: усний (індивідуальне і фронтальне опитування), письмовий (тестування, виконання завдань самостійної роботи, виконання модульних контрольних робіт) i комбінований (розроблення проектних робіт). Підсумковий контроль проводився методом тестування в середовищі Moodle.

\section{2. Використані ресурси і види діяльності в системі Moodle для викладання пропедевтичного курсу}

Варто зауважити, що структурування курсів на факультеті інформатики НПУ імені М. П. Драгоманова є уніфікованим. Зокрема, приведеними до єдиної форми, $\epsilon$ наявність необхідних для кожного курсу елементів (дидактична карта дисципліни (рис. 2); секції, об’єднані в модулі відповідно до дидактичної карти; тест підсумкового контролю; формула перерахунку балів у 100 бальну шкалу) і формат курсу (а саме, тижневий) (рис. 3). Водночас за викладачами залишається право структурувати курс індивідуально в контексті аудиторного навантаження (лекцій, практичних, семінарських, лабораторних занять, підсумкових робіт, індивідуальних завдань тощо). 
Передусім необхідно сказати про вступний розділ дистанційного курсу (рис. 1), який $є$ візитною карткою, тому важливо наповнювати його максимально інформативно, водночас не перенасичувати ресурсами чи видами діяльності.

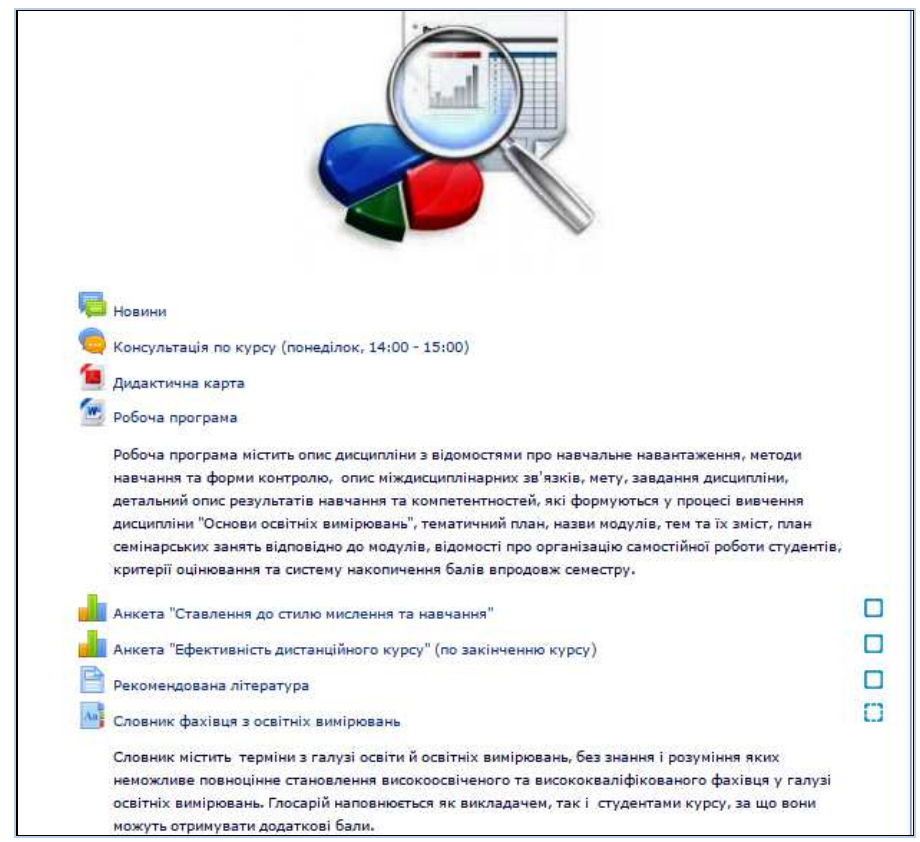

Рис. 1. Вступний розділ дистаниійного курсу «Основи освітніх вимірювань»

Для наповнення вступного розділу курсу «Основи освітніх вимірювань» використано перелік таких видів діяльності:

- анкета, зокрема, «Ставлення до стилю мислення та навчання», яка проводилася на початку вивчення дисципліни, щоби познайомитися зі студентами нової групи, й «Ефективність дистанційного курсу» наприкінці вивчення, щоби зрозуміти ефективність реалізованого курсу з погляду релевантності, інтерактивності, рівнів підтримки викладача й одногрупників;

- әлосарій для вивчення основних понять і термінів (як показала практика важливо, щоби студенти теж мали змогу додавати статті до глосарію, що не лише посилює їхню активну участь у наповненні курсу, але і сприяє кращому запам'ятовуванню введених термінів);

- чam, щоб організувати консультацію для студентів у зручний для викладача час, не прив'язуючись до конкретного місця проведення.

Також були використані ресурси:

- файл для розміщення дидактичної карти і робочої програми дисципліни «Основи освітніх вимірювань» (зауважимо, що, на нашу думку, найзручнішою формою представлення файлу в зазначеному випадку $\epsilon$ вбудований документ (рис. 2));

- сторінка для представлення списку необхідної і рекомендованої літератури. 


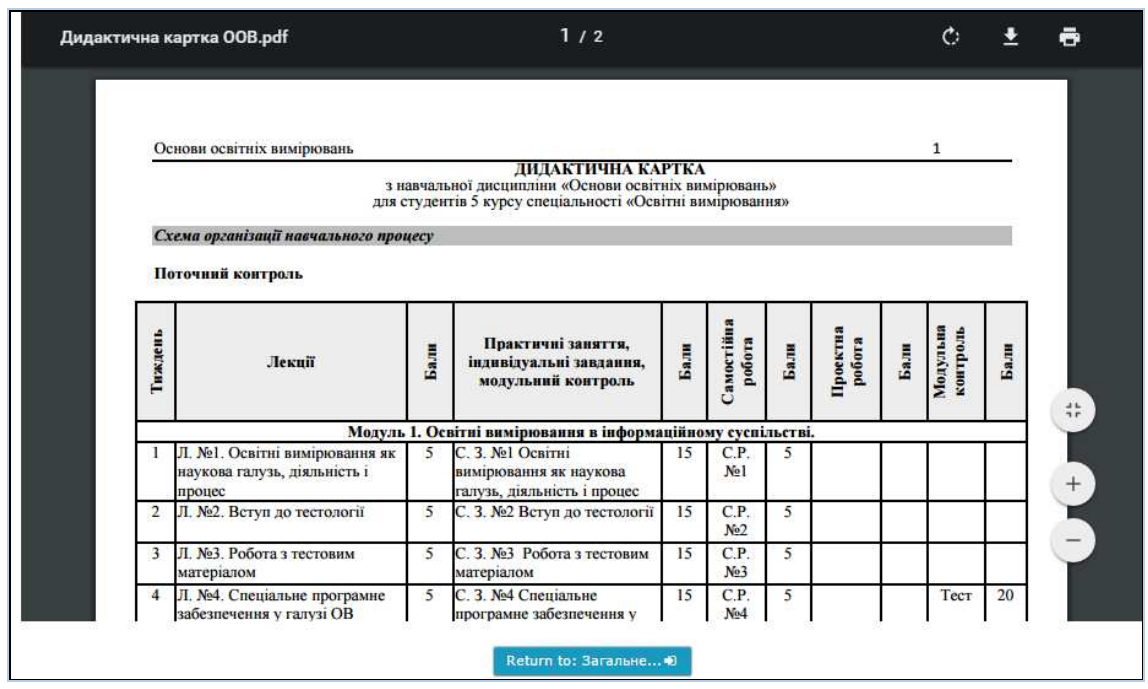

Рис. 2. Фрагмент дидактичної карти дисципліни «Основи освітніх вимірювань»

Наступні розділи курсу відповідають кількості модулів (у нашому випадку їх два), що так само структуровані в секції, кожна з яких містить матеріал однісї теми. Так, на рис. 3 подано зразок секції, що відображає перший тиждень навчання.

Для наповнення секції нами застосовано вид діяльності «Завдання», адже цей вид діяльності $є$ одним із тих, які оцінюються та $є$ простими у використанні, що важливо у випадку, коли дистанційний курс реалізується вперше. У майбутньому планується застосування більшої різноманітності видів діяльності з метою викладу потрібного матеріалу й організації навчального процесу.

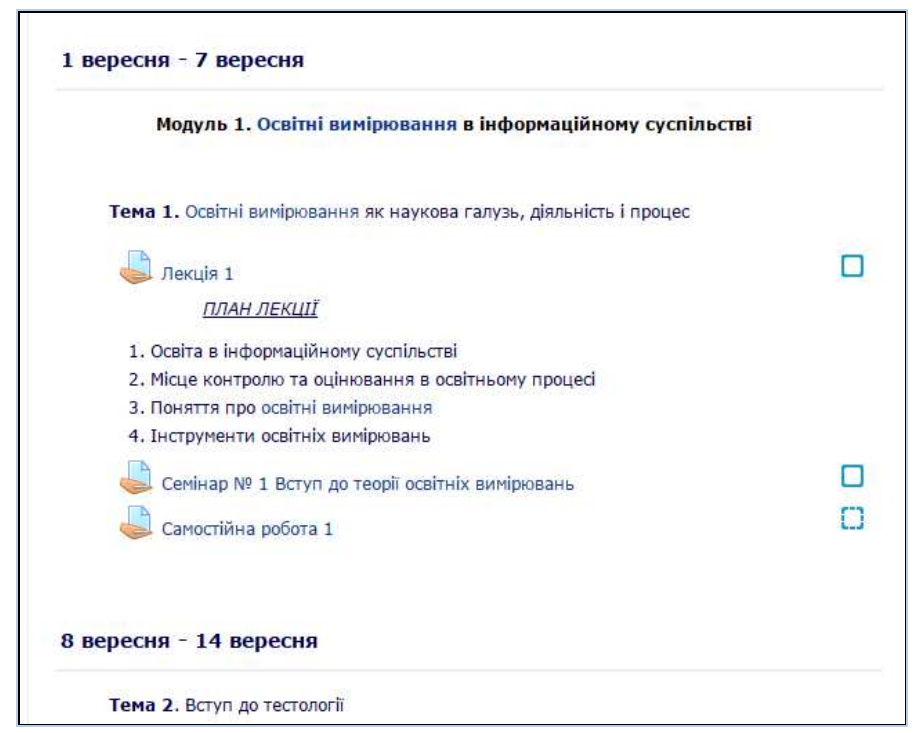

Рис. 3. Зразок секиії дистаниійного курсу «Основи освітніх вимірювань»

Як показала практика, студентам зручно бачити план лекції відразу під темою без необхідності переходити за різними посиланнями для цього. Такий підхід зручний під час підготовки до підсумкового контролю, коли потрібно знайти відповідь на конкретне запитання і відкрити необхідну лекцію. Але можливості додати перелік пунктів плану в опис завдання, де розміщено презентацію, немає. Тому для розміщення плану лекції використано ресурс «Напис» (рис. 3). 
У завданні «Лекція» студенти можуть ознайомитися з презентацією, яка доступна для перегляду без потреби завантаження (рис. 4).

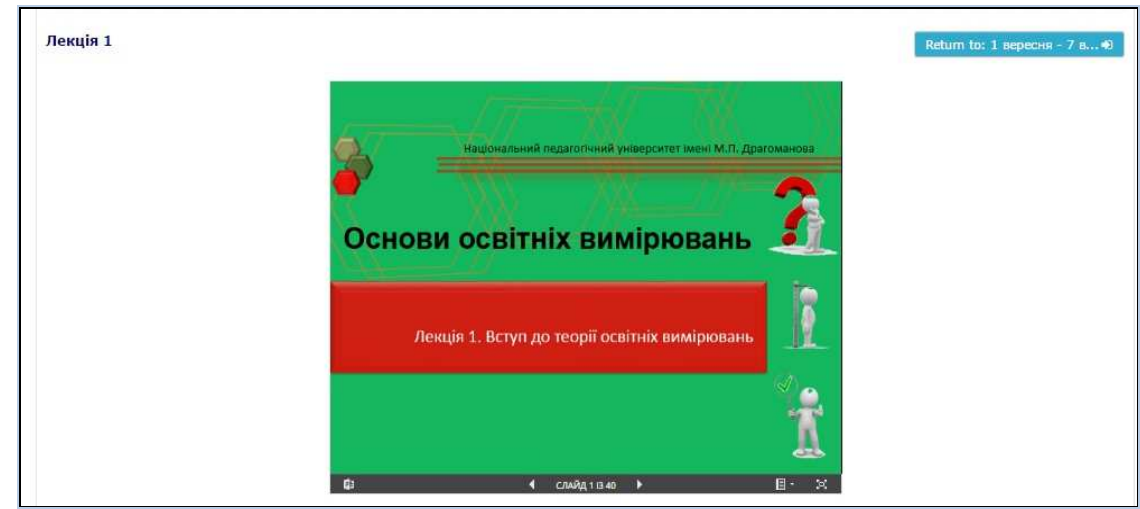

Рис. 4. Презентація лекиії в дистанизійному курсі

Функція вбудовування зовнішнього файлу доступна, якщо презентація розміщена, наприклад, у хмарному сервісі Microsoft Office 365. У цьому випадку, скопіювавши із Office 365 код вбудування відповідної презентації лекції та вставивши його в зміст завдання в Moodle, презентація буде доступна для перегляду в дистанційному курсі (рис. 5). Цей формат розміщення презентації зручний ще й тому, що якщо вносити зміни до презентації в сервісі OneDriveOffice 365, зміни автоматично враховуватимуться в системі Moodle.

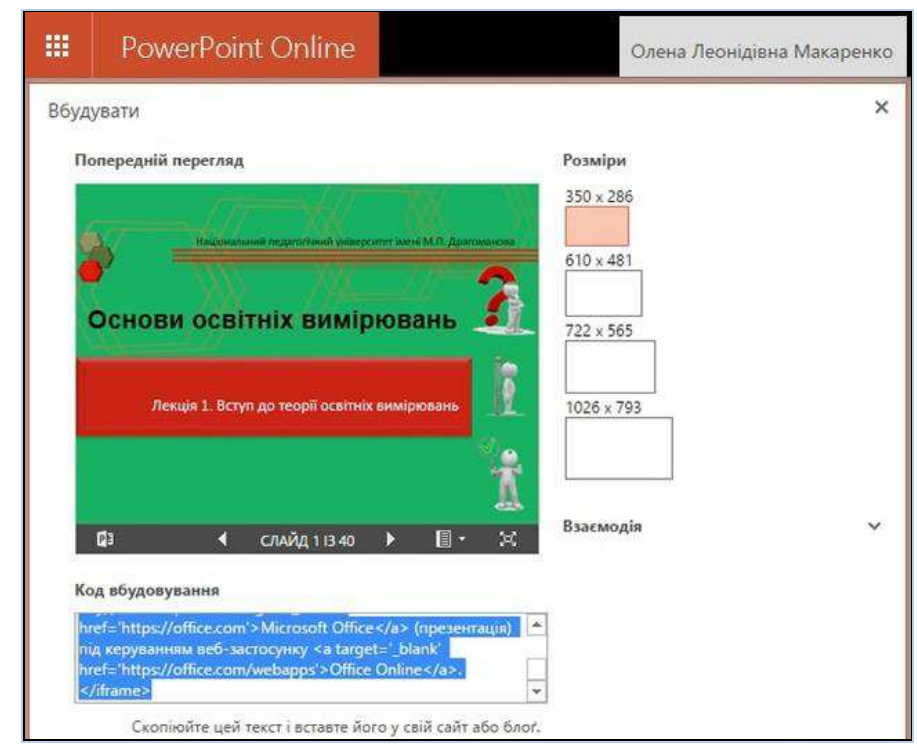

Рис. 5. Копіювання коду вбудування для розміщення презентації лекиії в систему Moodle

Кожен з елементів секції, доданих у формі «Завдання» оцінювався і відображався в електронному журналі оцінок (рис. 6.). Мова йде про оцінки: за короткий тест на початку семінарського заняття, за надіслане виконане завдання, отримане студентом наприкінці семінарського заняття, за модульну контрольну роботу, групову проектну роботу та підсумковий тест. Оцінки за усне опитування, активність на семінарах заносилася в електронний журнал у ручному режимі. 


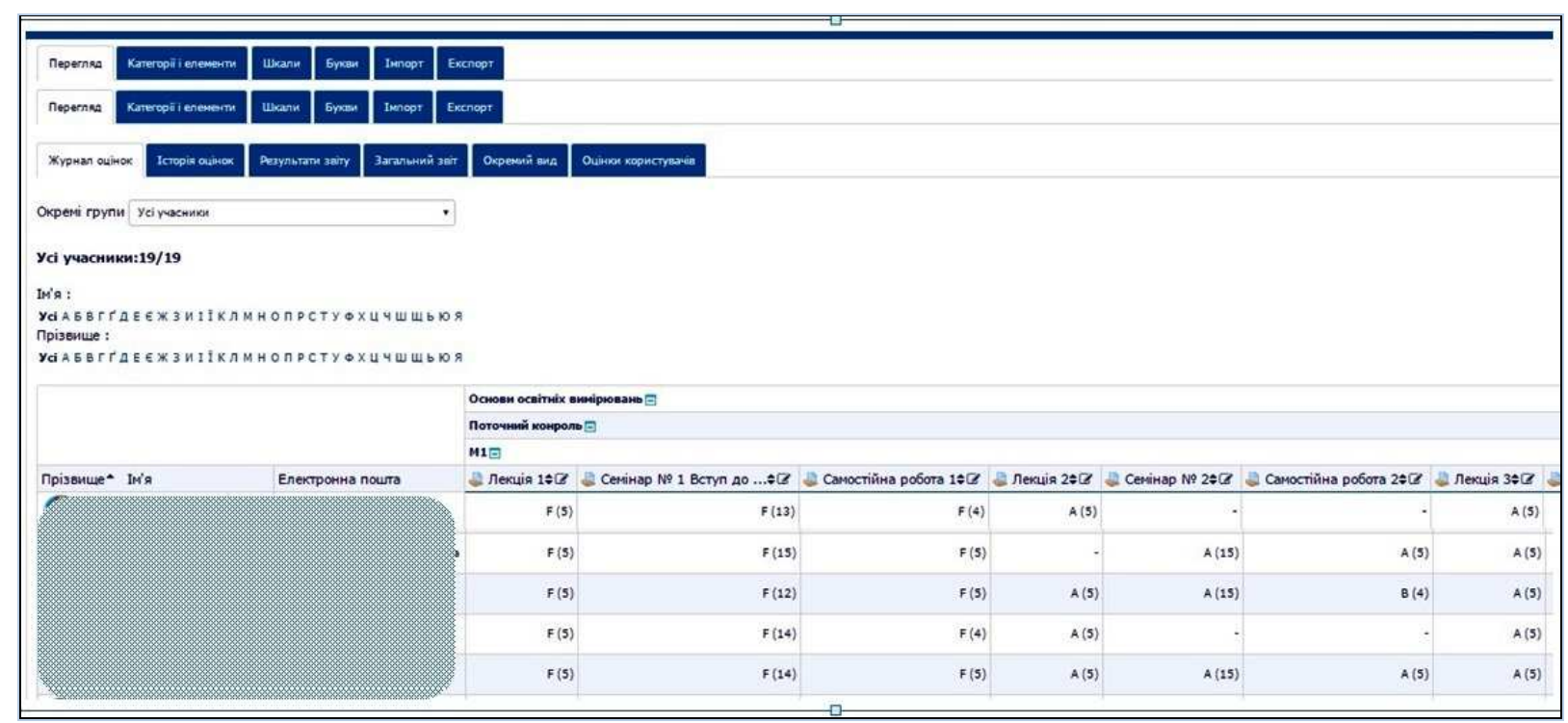

Рис. 6. Фрагмент електронного журналу оцінок дистаниійного курсу

\section{3. Значущість застосування дистанційного курсу на основі результатів анкетування}

Система Moodle пропонує низку стандартних анкет, серед яких «Ефективність дистанційного курсу». Опитування магістрантів спеціальності «Освітні вимірювання» 3 допомогою цього виду діяльності допомогло зрозуміти переваги i недоліки розробленого курсу як зі змістової, так і з організаційної сторін питання.

Анкета складається з шести блоків, що мають за мету перевірку релевантності, рефлексивного мислення, інтерактивності, рівня підтримки викладача й однокурсників. У кожному з блоків міститься 8 тверджень (рис. 7), кожне 3 яких передбачає, що студент встановить відповідність даного твердження певному значенню шкали, зважаючи на свій ідеал і фактичне враження від того, як те, чи інше твердження реалізувалося під час вивчення курсу.

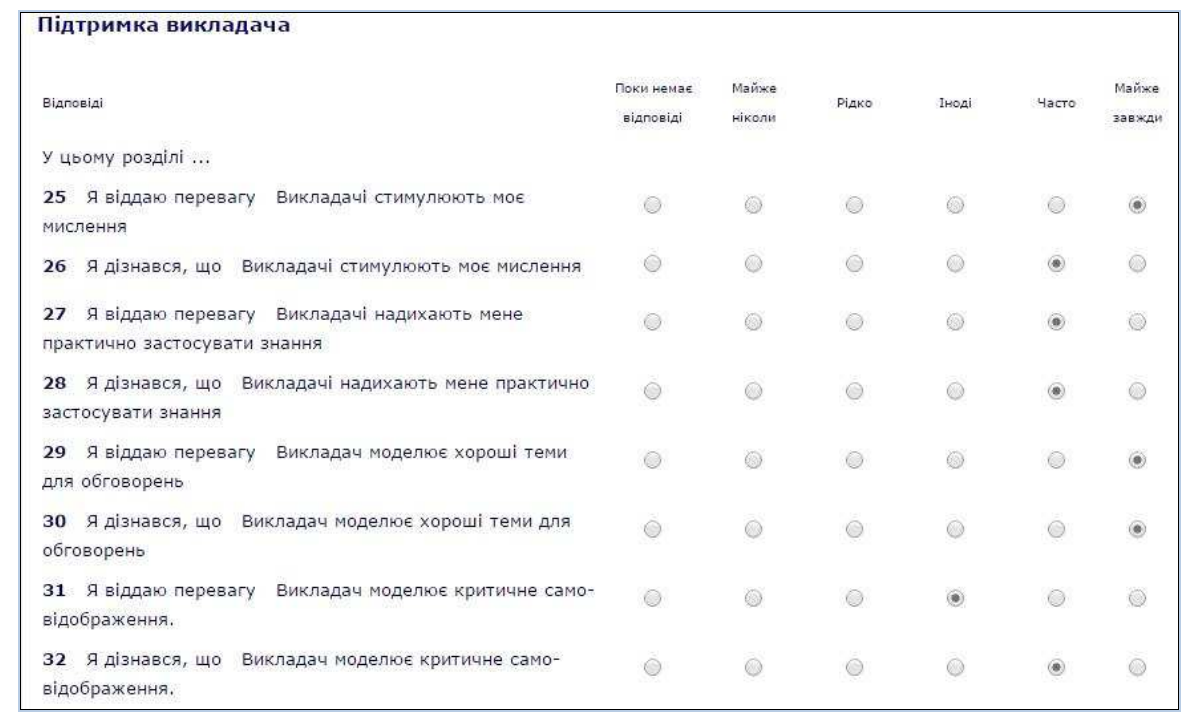

Рис. 7.Фрагмент анкети «Ефективність дистанційного курсу» 
Немає правильних чи неправильних відповідей, лише відповідність твердження елементам шкали: «Майже ніколи - рідко - іноді - часто - майже завжди». Усі питання обов'язкові й на них повинні бути відповіді.

Результати анкетування інтерпретуються в кількох формах. Зокрема, можна завантажити відповіді респондентів у форматах ODS, MSExcel чи текстовому редакторі. Проте, на нашу думку, найпрактичнішим є представлення підсумків у графічній формі (рис. 8), зокрема у формі загальної діаграми-висновку, або ж діаграм, за якими можна проаналізувати ефективність курсу за кожним окремим твердженням анкети чи відміткою шкали.

Діаграма на рис. 8 показує, що дистанційний курс реалізовано на достатньому рівні, але, без сумніву, є прогалини, які необхідно усувати, і показники, над якими необхідно працювати. Найнижчими за результатами виявилися показники «Рефлексивне мислення» і «Підтримка одногрупників», що вказує на важливість формування сприятливішого навчального середовища і збільшення кількості завдань для роботи в групах.

3 діаграми також зрозуміло, що є певна розбіжність в отриманому студентами результаті й очікуваному. Для удосконалення курсу варто звернути увагу на фокусуванні уваги студентів магістратури на тому, що теми, які вивчаються, стануть їм у пригоді в професійній практиці.

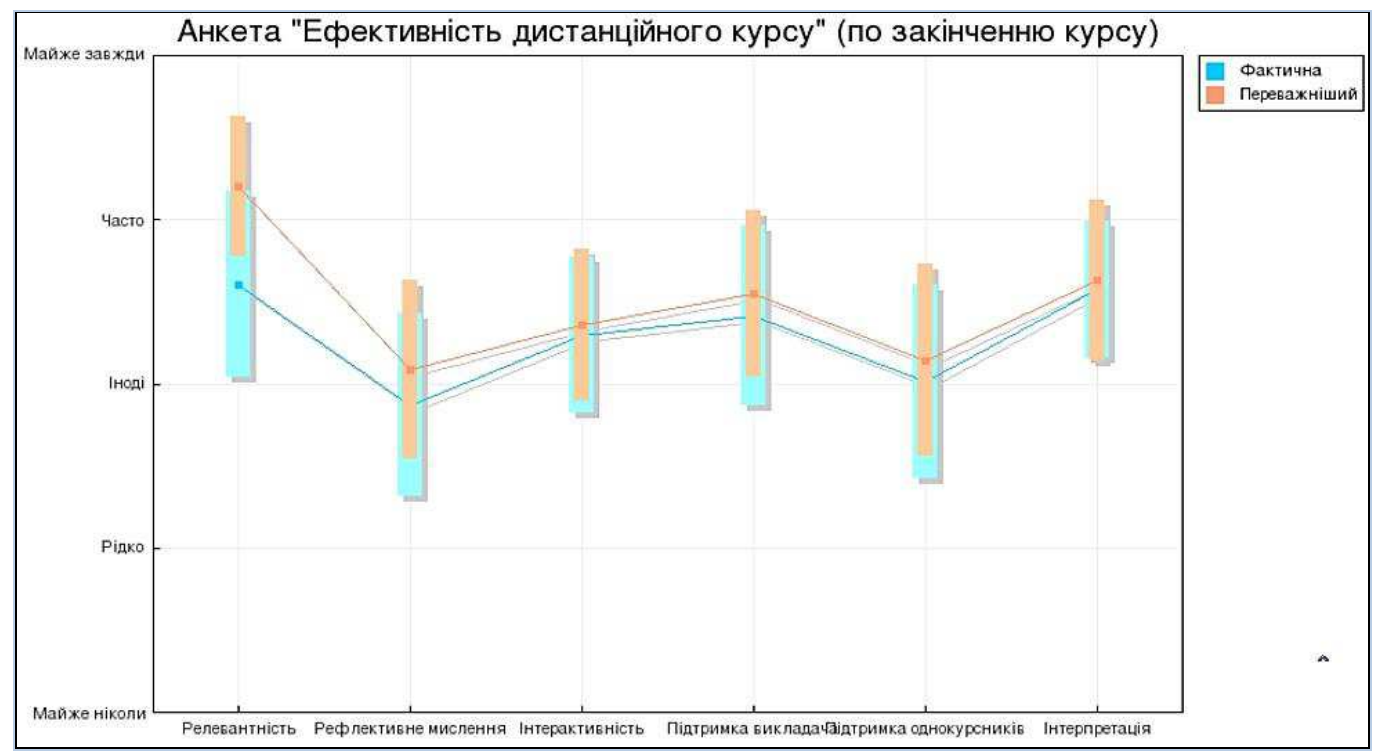

Рис. 8. Діаграма звіту про проведення анкетування

\section{4. ВИСНОВКИ ТА ПЕРСПЕКТИВИ ПОДАЛЬШИХ ДОСЛІДЖЕНЬ}

Уперше реалізувавши курс «Основи освітніх вимірювань» у навчальному процесі професійної підготовки магістрів з освітніх вимірювань із використанням засобів системи Moodle, ми переконалися в багатьох ії перевагах, деякі з них:

1) цілодобовий доступ до матеріалів навчальної дисципліни;

2) систематизація навчальних матеріалів і структурування курсу;

3) широкий вибір ресурсів і видів діяльності для організації навчання;

4) підвищення мотивації студентів до навчання завдяки розумінню ними того, якого кінцевого результату вони мають досягти. 
Однак, працюючи в такому комбінованому форматі, ми зіштовхнулися зі складнощами, серед яких недостатня мотивація студентів до використання тих ресурсів і видів діяльності, за виконання яких не передбачені оцінки в електронному журналі, а також великі часові затрати викладача в роботі над курсом, його плануванням, розробленням, наповненням, коригуванням тощо.

Проте, у загальному, ця форма роботи зі студентами рівня магістратури показала свою доцільність і практичність у формуванні необхідних результатів навчання i компетентностей.

Напрями подальших досліджень полягають у роботі над виявленими недоліками і комплексному удосконаленні дистанційного курсу «Основи освітніх вимірювань».

\title{
СПИСОК ВИКОРИСТАНИХ ДЖЕРЕЛ
}

1. Методичні вказівки до вивчення курсу «Робота викладача в WEB-орієнтованій системі підтримки навчального процесу Moodle» // [Гавриленко В. В., Попенко В. Д., Сокульський О. С., Шумейко О. А.] - К. : НТУ, 2012. - 49 с.

2. Методичні рекомендації зі створення тестових завдань та тестів у системі управління навчальними матеріалами MOODLE 2.5.x // [Сергієнко В. П., Франчук В. М., Кухар Л. О., Галицький О. В., Микитенко П. В.] - К. : НПУ імені М. П. Драгоманова, 2014. - 100 с.

3. Підготовка фахівців з освітніх вимірювань в Україн і: [навчально-методичний комплекс] / [О. В. Авраменко, Ю. О. Ковальчук, В. П. Сергієнко, Л. О. Кухар, Р. Я. Річняк] / за заг. ред. Д. С. Сільвестрова. - Ніжин : Видавець ПП Лисенко М. М., 2012. - - Частина 1. - 362 с.

4. Підготовка фахівців 3 освітніх вимірювань в Україні : [навчально-методичний комплекс] / [О. В. Авраменко, Ю. О. Ковальчук, В. П. Сергієнко, Л. О. Кухар] / за заг.ред. О. В. Авраменко. Ніжин: Видавець ПП Лисенко М. М., 2012. - - Частина 2. - 398 с.

5. Подласов С. О., Матвійчук О. В., Бригінець В. П. Організація самостійної роботи студентів у середовищі LMSMoodle// Педагогічні науки : збірник наукових праць / наук. ред. Федяєва В. Л. Херсонський державний університет : ВД «Гельветика», 2016. - С. 58-63.

6. Сергіснко В.П. Методичні рекомендації зі створення тестових завдань та тестів у системіуправління навчальними матеріалами MOODLE // В. П. Сергієнко, В. М. Франчук. - К. : НПУ імені М. П. Драгоманова, 2012. - 58 с.

7. Триус Ю. В. Система електронного навчання ВНЗ на базі Moodle: методичний посібник // Ю. В. Триус, І. В. Герасименко, В. М. Франчук / за ред. Ю. В. Триуса. - Черкаси, 2012. - 220 с.

8. Умрик М. А. Організація дистанційного навчання для забезпечення потреб сучасних студентів. Інформаційні технології і засоби навчання // Електронне наукове фахове видання «Інформаційні технології і засоби навчання». - 2015. - № 1 (45). - С. 146-155. Доступно за адресою: <http://journal.iitta.gov.ua/index.php/itlt/article/view/1175/889>. Дата доступу: 08 aug. 2016.

Матеріал надійшов до редакиії 12.10.2016 p.

\section{ПРЕПОДАВАНИЕ ДИСЦИПЛИНЫ «ОСНОВЫ ОБРАЗОВАТЕЛЬНЫХ ИЗМЕРЕНИЙ» С ИСПОЛЬЗОВАНИЕМ СРЕДСТВ СИСТЕМЫ МООDLЕ}

\author{
Макаренко Елена Леонидовна \\ аспирант, преподаватель кафедры компьютерной инженерии и образовательных измерений \\ Национальный педагогический университет имени М. П. Драгоманова, г. Киев, Украина \\ olmakarenko0307@gmail.com
}

\begin{abstract}
Аннотация. Средства дистанционного обучения все чаще используются в университетах во время аудиторной учебной деятельности. Такая практика имеет место и в Национальном педагогическом университете имени М. П. Драгоманова в процессе подготовки магистров по образовательным измерениям. Статья посвящена освещению вопроса использования средств системы Moodle в процессе преподавания курса «Основы образовательных измерений» для студентов магистратуры дневной и заочной форм обучения. Описаны структурные элементы дисциплины и их содержание. Представлен опыт наполнения
\end{abstract}


дистанционного курса дисциплины с использованием функционала системы Moodle для проведения лекционных и семинарских занятий, контроля выполнения студентами требований программы и оценки уровня усвоения ими учебного материала.

Ключевые слова: магистры по образовательным измерениям; подготовка; магистратура; дистанционный курс, преподавание дисциплины; Moodle.

\title{
TEACHING OF THE COURSE "FUNDAMENTALS OF EDUCATIONAL MEASUREMENTS" USING TOOLS OF THE MOODLE
}

\author{
Olena L. Makarenko \\ postgraduate student, teacher of Computer Engineering and Educational Measurement Department \\ National Pedagogical Dragomanov University, Kyiv, Ukraine \\ olmakarenko0307@gmail.com
}

\begin{abstract}
Distance learning tools are increasingly being used at universities in the classroom learning activities. This practice takes place at the National Pedagogical Dragomanov University. The article is devoted to highlighting the practical implementation of the learning process course «Fundamentals of educational measurements» for masters of this specialty. It is described structural elements of discipline, their content and the basic aspects of using system Moodle. It is shown the experience of: structuring of distance course; using of functional environment Moodle for lectures and seminars; monitoring and evaluating of students achievements.
\end{abstract}

Keywords: educational measurement; distance course; master's degree; Moodle.

\section{REFERENCES (TRANSLATED AND TRANSLITERATED)}

1. Mariia A. Umryk Organization of distance learning for meeting the needs of modern students. Information Technologies and Learning Tools, [S. 1.], v. 45, n. 1, p. 146-155, feb. 2015. ISSN 2076-8184. <http://journal.iitta.gov.ua/index.php/itlt/article/ view/1175/889> (in Ukrainian)

2. Methodological guidelines for thecreationoftest items andtestsinthe LMS MOODLE 2.5.x // [SergiienkoV. P., FranchukV. M., Kuhar L. O., GalytskyO. V., MykytenkoP. V.]. - K.: Dragomanov NPU, 2014. - 100 p.(in Ukrainian).

3. Methodological guidelines for the study course «The work of the teacher in the WEB-based system forthe support of the educational process Moodle» / [V. V. Havrylenko, V. D. Popenko, O. Ye. Sokulskyi,O. A. Shumeiko]. -K. : NTU, 2012. - 49 p. (in Ukrainian).

4. Podlasov S. O., Matviichuk O. V., Briginets V. P. Organization of independent work of students in the LMSMoodle : Collection of scientific papers / Pedagogical Science, - Issue LXXI. Part 1., 2016. -P. 58 - 63. ISSN 2413-1865 <http://ps.stateuniversity.ks.ua/file/issue_71/part_1/13.pdf >(in Ukrainian).

5. Sergiienko V. P. Guidelines for the creation of test items andtestsinthe LMS MOODLE / V. P. Sergiienko, V. M. Franchuk. K. :Dragomanov NPU, 2012. - 58 p. (inUkrainian).

6. Training of educational measurement in Ukraine [educational-methodical complex] / O. V. Avramenko, Yu. O. Kovalchuk, V. P. Sergiienko, L. O. Kukhar; under gen. ed. D. S. Silvestrov. - Nizhyn: PP Lysenko M. M. Publishing, 2012. - Part 1. - 362 p. (in Ukrainian)

7. Training of educational measurement in Ukraine [educational-methodical complex] / O. V. Avramenko, Yu. O. Kovalchuk, V. P. Sergiienko, L. O. Kukhar; under gen. ed. O. V. Avramenko. - Nizhyn: PP Lysenko M.M. Publishing, 2012. - Part 2. - 398 p. (in Ukrainian)

8. Tryus Yu. V. University e-learning system based on MOODLE : Toolkit/ Yu. V. Tryus, I. V. Herasymenko, V. M. Franchuk // under gen. ed. Yu. V. Tryusa. - Cherkasy, 2012. - 220 s. (in Ukrainian).

Conflict of interest. The author has declared no conflict of interest.

\section{(c) BY-NC-SA}

This work is licensed under Creative Commons Attribution-NonCommercial-ShareAlike 4.0 International License. 